\title{
La loi de divergence: Discussion
}

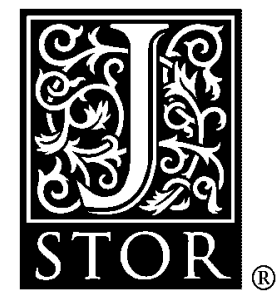

J. Tinbergen; Tjalling C. Koopmans; Jacob Marschak; Francois Divisia; Jacques Rueff; B. Chait

Econometrica, Vol. 17, Supplement: Report of the Washington Meeting. (Jul., 1949), pp. 124-128.

Stable URL:

http://links.jstor.org/sici?sici=0012-9682\%28194907\%2917\%3C124\%3ALLDDD\%3E2.0.CO\%3B2-K

Econometrica is currently published by The Econometric Society.

Your use of the JSTOR archive indicates your acceptance of JSTOR's Terms and Conditions of Use, available at http://www.jstor.org/about/terms.html. JSTOR's Terms and Conditions of Use provides, in part, that unless you have obtained prior permission, you may not download an entire issue of a journal or multiple copies of articles, and you may use content in the JSTOR archive only for your personal, non-commercial use.

Please contact the publisher regarding any further use of this work. Publisher contact information may be obtained at http://www.jstor.org/journals/econosoc.html.

Each copy of any part of a JSTOR transmission must contain the same copyright notice that appears on the screen or printed page of such transmission.

JSTOR is an independent not-for-profit organization dedicated to and preserving a digital archive of scholarly journals. For more information regarding JSTOR, please contact support@jstor.org. 


\section{Discussion}

\section{Professor Tinbergen:*}

I have very little to add to the valiant summary given by Frofessor Divisia of Dr. Chait's very important work. But permit me in a few minutes just to add some remarks of my own which might further clarify to you the true nature of Dr. Chait's work.

I think the particularly interesting feature is that he brings stocks and equipment into the same group of phenomena, and next that many of his results are obtained by applying one experimental relation, namely the relation of proportionality between stocks and sales, a relation that in many cases has been established by statistical observation. That very simple relation, if applied to a chain of markets, in fact introduces differential equations of a higher order than the first order only; and it is by the combination of these two sorts, namely the linear relationship between stocks and sales on one hand, and the fact that he considers a number of markets that are placed behind each other, that he gets the possibility of explaining economic fluctuations even without introducing lags: something that is interesting from the purely theoretical point of view.

On the other hand, as Professor Divisia has very clearly pointed out, Dr. Chait doesn't dwell upon this special case. He also gives us more general possibilities. And I might perhaps end by telling you that just at this moment, at the National Bureau of Economic Research, interesting statistical investigations are going on, relating to such a system of markets. I hope very much that that will give us an opportunity of bringing into the center of attention some of Dr. Chait's ideas.

\section{Professor Koopmans:}

I would like to ask some clarification on the following point: What types of equations do occur in Mr. C h a i t's system? As I understand it, Mr. Chait aims at an explanation of economic fluctuations by the use of an equation system; and, from the explanations that have been given by Frofessor D i vis i a and Professor T i n b e r g e n, I understand that these equations are of at least two types. One type of equations could be described as an identity (the type of equation that occurs in hy. drodynamics) which says that the total amount of goods going into a

* Since Mr. Chait was not able to be present, his paper was presented by Professor Divisia, and the discussion by Professors Tinbergen and Divisia and others is inclu. ded for completeness. 
certain domain less the amount of goods going out of it must be balanced by the change of the stocks in that domain. This can be declared to be an identity. Now in addition to that Mr. Tinbergen has also mentioned something that, if I understand him correctly, is a behavior equation which says that stocks are held proportional to sales; in any case that was so in one of the alternatives considered by Mr. Chait.

My question is the following: Does the putting together of these two types of equations, flow identities and proportionality between stocks and sales, suffice to create a complete system from which economic fluctuations can be consistently and fully explained?

\section{Professor Tinbergen:}

I think the situation is this, that Dr. $\mathrm{C} \mathrm{h}$ a i t paid particular attention to the two types of equations that have now been discussed. As to the other equations that of course are necessary in order to complete his system, he doesn't make, as far as I am aware, assumptions that are different from the assumptions that we are accustomed to or, I may say, we were accustomed to in 1936 when he wrote his book. So, although he certainly pays some attention to these questions, it is not that part of his book which is the most original part, I think in some of his examples, for instance, he assumes that total demand is determined by income in the way it is done by the Keynesian equations. I am not sure whether he introduces in any of his examples some laws about price formation or whether he-as $\mathrm{K}$ e $\mathrm{y} \mathrm{n}$ e s did-makes the system into some sort of a real system only. But the chief thing to be said is that the new elements in his systems are the elements indicated by Professor Divisia.

\section{Professor Marschak:}

Perhaps the system will have a periodic solution if, in addition to time-derivatives, Mr. C h a it has time-lags, corresponding to the production periods of various firms?

\section{Professor Tinbergen:}

Dr. C h a it, I think, considered two cases. First of all, he considered the case where the lags do not exist or are negligible. In that case he nevertheless succeeds in getting a theory of fluctuations by the very fact that more than two succeeding markets are considered, or even for one market, if industrial or commercial equipment is introduced as a variable. And next, he contains derivatives of $Z_{i-1}$ (maybe of different orders) meant to represent the enterpreneurs' reactions. The final result may be a variable between $Z_{i-1}$. The lag is not introduced a priori, but explained by the various derivatives and the consequences is that it need not be constant, 


\section{Professor Divisia:}

Je voudrais simplement fournir un complément de renseignement à Mr. K o o p mans sur la question qu'il a posée. Le travail de M. Cha i t, autant que j'aie compris, n'est pas du tout une tentative d'explication des cycles: c'est beaucoup plus. M. Chait m'a dit qu'il a eu l'idée de son travail, alors qu'il se promenait dans une usine de fabrication à la chaîne. L'idée lui est aussitôt venue à l'esprit que la vie économique, c'est tout simplement une chaîne. Et cette idée a pris figure dans une peinture. Sachant les mathématiques, il a fait la peinture en équations. Il a trouvé ainsi, la possibilité de tirer de là toutes sortes d'idées sur des observations à faire,-ce qui est fort important-et d'ores et déjà, toutes sortes de conclusions. Tout au moins dans sa première étude, mais, je crois, également dans son livre, M. Chait a, avant tout, considéré la solidarité la plus générale qui s'exerce entre tous les marchés, par récurrence sur le réseau de filières. Ce n'est qu'ensuite qu'il a envisagé toute une série de cas concrets, en vue de trouver, par l'investigation statistique, les équations qui lui manquaient. C'est ainsi qu'il est tombé sur des solutions touchant au problème des oscillations, mais on pourrait presque dire que ce ne sont là que des cas d'application ce sa présentation théorique générale. Je crois vraiment qu'il a été beaucoup plus loin que la seule étude des cycles, par un très bel effort d'abstraction. Cet effort est tellement général et a abouti à un mécanisme tellement abstrait, qu'il garde sa valeur, pour quelqu'explication particulière que ce soit.

\section{Rueff:}

J'ai été extrêmement intéressé par le résumé qu'a présenté $M$. Divisia. Je ne connais pas l'ouvrage de M. Chait, mais j'avais moimême rencontré sur ma route la notion de "flux."

J'ai indiqué à la page 35 de la première édition de mon Ordre Social limportance qu'elle me paraissait présenter. Je crois, en particulier, que les phénomènes économiques n'entreront commodément dans le temps que lorsqu'ils seront décrits par le langage des flux.

Je voudrais vous indiquer rapidement comment je vois l'utilisation de la notion de flux en théorie monétaire.

Je considère, non comme M. Chait, l'entreprise, mais le marché.

En chaque période de temps le volume des droits qui viennent se vider, sur le marché, c'est le flux d'entrée; le volume des droits qui viennent se remplir, c'est le flux de sortie.

Cette présentation conduit immédiatement à la théorie de variations du niveau général des prix. En effet, tant que le premier des flux est égal au second, le niveau général des prix reste inchangé. 
Or, il ne peut y avoir différence entre les deux flux que s'il y a différence entre le montant global des encaisses effectives et celui des encaisses désirées.

Je n'insiste pas. Je veux seulement marquer que je suis entièrement d'accord avec M. Divisia-donc avec M. Chait-pour penser que la théorie des flux est un puissant instrument d'analyse économique.

\section{Professor Divisia:}

Je voudrais dire à $M . R$ u e f $f$, que, effectivement, l'observation qu'il vient de faire, porte sur un aspect du travail de M. C h a it (ou un prolongement de ce travail) que pour ma part, je considère comme essentiel. Je ne crois pas que M. Chait ait déjà publié des développements sur ce point, mais cela, à mon avis, n'a aucune importance parce que c'est inéritablement inclus dans sa présentation.

M. Chait s'est d'abord borné à nous décrire un réseau de filières matérielles, traitant de quantités de biens. Mais au bout de la filière, nous arrivons aux produits de consommation finale, qui s'échangent les uns contre les autres. Or ils s'échangent sur le pied de leurs valeurs, si bien qu'on est inévitablement conduit à considérer, après le réseau de flux des biens matériels en quantité, le même réseau de flux mais en valeurs. Là encore, il y a pour chaque entreprise, un flux d'entrée, un flux de sortie et un stock, qui n'est autre que le montant de l'actif diminué du profit nominal cumulé. Et alors, si on considère, ces deux réseaux de filières se correspondant noeud à noeud et flux à flux, l'ún où coulent des quantités de richesses, l'autre où coulent des valeurs; le prix $\mathrm{y}$ apparaît comme le quotient des flux en deux points correspondants de ces résaux. Car un flux de valeur divisé par un flux de quantité, c'est un prix. Vous voyez qu'on arrive à une définition extrêmement générale du prix, qui en particulier, est complètement indépendante du régime politique.

D'autre part, si nous regardons avec M. Chait, l'ensemble de l'économie comme un vaste travail à la chaine, nous sommes obligés de nous dire que, si les biens matériels circulent, il y a autre chose aussi qui circule, qui est la monnaie. Et alors $M$. Chait nous a donné du même coup, une description des filières monétaires avec, encore, pour chaque élément un flux d'entrée, un flux de sortie, et un stock. Les flux de monnaie sont égaux, et de signes contraires, aux flux de valeurs ci-dessus; et le stock de monnaie dans l'entreprise c'est sa trésorerie. Il y a là, par conséquent, ce que, pour ma part, je considère comme la fondation de la théorie monétaire, dont l'aspect qu'elle présente ici n'est pas autre chose que la théorie des stocks appliquée aux signes monétaires.

J'ai l'impression que la présentation très abstraite de M. Chait aura d'énormes retentissements, en donnant lieu à toutes sortes de 
cristallisations concrètes fort importantes. Justement dans cette direction il y en a une, que je veux signaler, en raison de son importance, c'est la théorie de la banque. Elle est incluse dans la correspondance entre le réseau des filières de marchandises et le réscau des filières de monnaie, au sens le plus large de ce mot; car au fond, si tous les crédits bancaires ont l'air d'être des crédits en monnaie, il sont, en réalité, des crédits en marchandises, puisque tout ce que l'homme fait, il le fait avec des marchandises et non avec de la monnaie. Et donc, pour connaître le volume des crédits disponibles, il faut connaître le comportement des stocks de marchandises disponibles dans les filières. Lorsque nous aurons franchi ce pas, nous aurons, je crois, vraiment une théorie efficiente en ce qui concerne la politique bancaire. Vous voyez comment, en définitive, nous retrouvons, dans la présentation abstraite générale de M. Chait, l'industrie, le commerce, la monnaie, la banque. Et peut-être son utilisation viendra-t-elle y ajouter encore quelques autres châpitres.

\section{Rueff:}

Je voudrais dire à $M$. D i v i s i a que je pense comme lui: l'étude des variations de prix peut être très efficacement approchée par comparaison entre le flux de marchandises et le flux de pouvoir d'achat.

Mais il est alors indispensable de mettre en lumière le lien qui existe entre les deux flux. Ils ne sont pas indépendants et, pour ma part, je n'ai réussi à dégager ce lien qu'en montrant qu'en chaque période le premier était identique au second, majoré des éventuelles divergences entre encaisses effectives et encaisses désirées.

Mr. Chait's paper was further discussed by Messrs. Everett E. Hagen, J. J. Polak, and Sidney Alexander. 